\title{
LUNGS HISTOLOGICAL CHANGES IN EXPERIMENTAL INTOXICATION WITH RELDAN 40 EC AT PELOPHYLAX RIDIBUNDUS (PALLAS, 1771)
}

\author{
Maria Cristina Ponepal ${ }^{1}$, Monica Marilena Țânțu${ }^{1}$, Magdalena Diaconu", Alina Păunescu ${ }^{1}$ \\ ${ }^{1}$ University of Pitesti, Faculty of Sciences, Physical Education and Informatics, \\ Târgu din Vale Street, Piteşti, Argeş, Romania \\ ${ }^{2}$ University of Medicine and Pharmacy of Craiova, Petru Rareș Street 2, Craiova, Dolj, Romania
}

\section{Natural Sciences}

\begin{abstract}
The objective of this paper is to study the histological changes induced by Reldan $40 E C$ in a dose of $0.01 \mathrm{ml}$ chlorpyrifos $/ g$ body weight at the level of the lungs of the amphibian specimens Pelophylax ridibundus (Pallas, 1771). The insecticide was administrated by intraperitoneal injection ( 1 injection at 2 days in a scheme for 2 weeks). Highly degenerative changes were observed in animals cultured at $22-24^{\circ} \mathrm{C}$, compared to those cultured at $4-6^{\circ} \mathrm{C}$ : thickness of alveolar septa, intraparietal, higher number of hypertrophied goblet cells, disorganization of blood capillaries, fibrosis.
\end{abstract}

Keywords: chlorpyrifos, lungs, frog

\section{INTRODUCTION}

Amphibians are the vertebrate group with the highest percentage of species listed by the International Union for Conservation of Nature (IUCN) as decreasing and threatened with extinction (Blaustein et al., 2010). Amphibians tend to be at higher risk from aquatic contaminants than other vertebrates because of their little mobility, life cycle complexity and high-water permeability skin (Gonzalez Mille et al., 2013). The decline of amphibian populations is primarily due to anthropogenic pollution and increasing use of pesticides and synthetic fertilizers (Houlahan et al., 2000; Sparling, 2003; Greulich and Pflugmacher, 2004; Hayes et al., 2006; Whittaker et al., 2013; Soloneski et al., 2016; Trudeau et al., 2020). Bridges and Boone, 2003 also considering that tadpoles may be exposed many times to residues of agricultural contaminants during development.

Pelophylax ridibundus Pallas, 1771, primarily known as Rana ridibunda, is a widely distributed marsh frog species of Europe, including in Romania (Török et al., 2019). P. ridibundus is a useful bioindicator can provide information in environmental risk assessment due to spending its whole life in the watershed (Marques et al., 2009; Zhelev et al., 2013; Zhelev et al., 2018) - quote from Şişman et al., 2020). The use of specimens of Pelophylax ridibundus as bioindicators of pollution of agricultural environments is also recommended by Zhelev et al., 2018. 
Reldan 40EC is an organophosphorus pesticide (insecticide, nematicide and acaricide) of the third toxicity group and has as active substance chlorpyrifos-methyl at a concentration of $400 \mathrm{~g} / \mathrm{l}$. Organophosphorus pesticides are increasingly used in agriculture and have in many cases replaced organochlorine and carbamate insecticides, due to its high efficacy and low persistence; at present they are used at the highest rates for both domestic and agricultural uses (Kiely et al. 2004; Casida and Quistad, 2004). Chlorpyrifos (CAS 2921-88-2) is a broad-spectrum organophosphorus insecticide applied world life with low persistence in outdoor environment (Koshlukova and Reed, 2014). Research has shown that runoff after heavy rains can remove up to a third of the amount of chlorpyrifos that was recently applied to soils (Beasley, 2020); chlorpyrifos in water bodies adjacent to agricultural fields at much higher concentrations - up to $700 \mathrm{mg} / \mathrm{L}$. Mode of action of chlorpyrifos is cholinesterase inhibition (El-Merhibi et al., 2004). LC50s for chlorpyrifos in developing anurans have ranged from 1 to $14 \mathrm{mg} / \mathrm{L}$ (Beasley, 2019). The LC50 values of chlorpyrifos for the frog $R$. cyanophlyctis at 24, 48, 72, and $96 \mathrm{~h}$ were 8.252, 7.254, 6.247 and $4.993 \mathrm{mg} / \mathrm{L}$, respectively (Srivastav et al., 2017); 96h LC50 value for embryos of Xenopus laevis was reported as $2.41 \mathrm{mg} / \mathrm{L}$ (El-Merhibi et al., 2004) and for tadpoles of Bufo bufo gargarizans has been reported as $0.80 \mathrm{mg} / \mathrm{L}$ (Yin et al., 2009). Bernabo et al., 2011 reported 96-h LC50 value of chlorpyrifos for $R$. dalmatina tadpoles of $5.174 \mathrm{mg} / \mathrm{l}$. Chlorpyrifos at concentrations as low as $25 \mu \mathrm{g} / \mathrm{L}$ caused developmental abnormalities (lateral tail flexure that would impair swimming) and severely malformed gills at tadpoles of Rana dalmatina; a concentration of only $1 \mu \mathrm{g} / 1$ stunted the growth and altered the brain structure of northern leopard frog (L. pipiens) tadpoles - Beasley, 2020.

Chlorpyrifos did not cause a concentration-related reduction in developmental rate of $R$. dalmatina tadpoles (Bernabo et al., 2011). In $R$. dalmatina tadpoles chronically exposed to chlorpyrifos $(0.025,0.05$ and $0.1 \mathrm{mg} / \mathrm{l})$, the first pathological effects observed in the gills after 8 days and preceded any other evident alterations such as deformities or behavioural disorders (Bernabo et al., 2011); the authors reported the following changes in the gills: mucous secretion, epithelium detachment and a degeneration phenomenon. Although at a concentration of $0.2 \mathrm{mg} / \mathrm{l}$, chlorpyrifos does not have the effect of reducing survival, does not influence the growth and development of Rana boylii and Pseudacris regilla tadpoles, but increases the duration of metamorphosis at higher concentrations. Changes in body weight and development as a result of exposure to chlorpyrifos $(0.1$ and $0.2 \mathrm{mg} / \mathrm{l})$ in four North American frog species was reported by Widder and Bidwell (2008). After exposure to chlorpyrifos, several authors reported consistent malformations such as spinal abnormality, flexure of the tail and oedema in X. laevis tadpoles (Richards and Kendall, 2002; Bonfanti et al. 2004; Colombo et al. 2005 - quote from Bernabo et al., 2011). A number of adverse effects of chlorpyrifos have been reported in vertebrates: hepatic dysfunction, immunological abnormalities, embryo toxicity, genotoxicity, teratogenicity, and neurochemical and neurobehavioral changes (Ali et al. 2009; Dam et al. 2000; Gomes et al. 1999; Rahman et al. 2002; Ricceri et al. 2006; Song et al. 1998 - quote from Bernabo et al., 2011).

Studies on the influence of this insecticide on amphibians are quite few (Giesy et al. 1999; Richards and Kendall 2002, 2003) and focus on Xenopus laevis, which is a widely used experimental model. In this paper we investigated the histopathological effects on the lungs of Pelophylax ridibundus adults induced by the insecticide Reldan 40EC at two thermal levels. 


\section{MATERIALS AND METHODS}

The biological material used is represented by adults of Pelophylax ridibundus, of both sexes, with an average weight of $56 \pm 1.8 \mathrm{~g}$. The acclimatization of the animals in the laboratory lasted 5 days in aquariums contained dechlorinated tap water. All care was taken to avoid giving stress to the frogs. Feeding was stopped $24 \mathrm{~h}$ before and during the experimental period. Throughout the experiment, animals were maintained under a natural light/dark cycle and median $\mathrm{pH}$ 7.3. During the experimental period, the presence of mortality was monitored, and dead animals removed.

The animals were divided into 6 groups of 10 frogs: the control groups at temperatures of $4-6{ }^{\circ} \mathrm{C}$ and $22-24^{\circ} \mathrm{C}$ and the experimental groups, in which the animals were injected with Reldan $40 \mathrm{EC}$ in a dose of $0.01 \mathrm{ml}$ chlorpyrifos/g body weight and keep at $4-6^{\circ} \mathrm{C}$ respectively at $22-24^{\circ} \mathrm{C}$. The insecticide was administrated by intraperitoneal injection (1 injection at 2 days in a scheme for 2 weeks).

At the end of the treatment, the animals were anesthetized with chloroform and were spinalized by a method indicated by Picoş and Năstăsescu (1988) and lung pieces were taken to assess histological changes via light microscope examination Tissues samples were fixed in $8 \%$ neutral formalin for poikilotherms for $24 \mathrm{~h}$. Samples were then processed using a graded ethanol series and embedded in paraffin. Paraffin section were cut $7 \mu \mathrm{m}$ - thick slices using a rotary microtome (Slee Maintz Cut 5062) and stained with: haematoxylin $(\mathrm{H})$ as a general screening method and Sirius red (Juncueira et al., 1979) for collagen stain (fibrosis). The sections were viewed and photographed using an Olympus microscope with an attached camera. Three replicates were used for each treatment and the control. Precautions were taken to remove the dead frog immediately because dead animals deplete dissolved oxygen.

\section{RESULTS AND DISCUSSIONS}

Lung, liver and kidney are the most preferred organs for histopathological investigations due to their roles in absorption, distribution, biotransformation, detoxification and excretion of xenobiotics (Păunescu et al., 2012). Chlorpyrifos is known to induce histological changes in lung tissue (Uzun et al., 2010).

During hibernation, which occurs from a temperature of $4^{\circ} \mathrm{C}$, frogs do not use their lungs, becoming inactive animals (Öztay, 2000). As the metabolism decreases, there are mainly functional changes. However, in the lung it can be seen that in the blood capillaries the erythrocytes are very close to the pneumocytes which are inactive. Also, erythrocytes are intensely stained, probably due to the accumulation of a larger amount of haemoglobin in order to use at a maximum level the minimum amount of air in the lung. The goblet cells also become inactive, containing in the apical cytoplasm numerous large secretory granules (Öztay, 2000), which give the appearance of honeycomb.

Reldan 40EC at a concentration of $0.01 \mathrm{ml}$ chlorpyrifos/g body weight causes poor histological changes in the lungs in animals kept at a temperature of $4-6{ }^{\circ} \mathrm{C}$ : an accentuated thickening of the conjunctive septa (especially of the first order) and the presence of numerous smooth muscle fibres in the septum walls along with numerous fibroblasts (figure 1).

The goblet cells hypertrophy and become inactive, and secretory granules are observed in their cytoplasm that no longer exocyte; pneumocytes have in their immediate vicinity hyaline erythrocytes, which no longer exchange respiratory gases (pneumocytes become inactive) and some blood capillaries become disorganized (figure 2). 


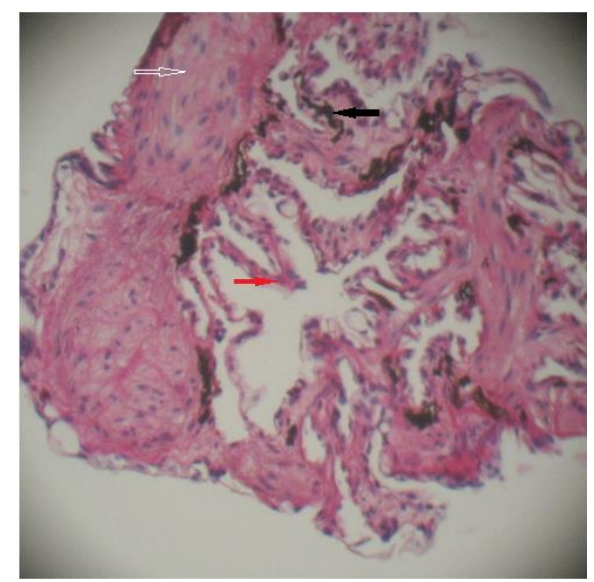

Figure 1. Cross-section through the lung of Pelophylax ridibundus treated with Reldan 40EC and kept at a temperature of 4-6 ${ }^{\circ} \mathrm{C}$. First order septa - white arrow, second order septa - black arrow, third order septa - red arrow. 100X. HE and Sirius red

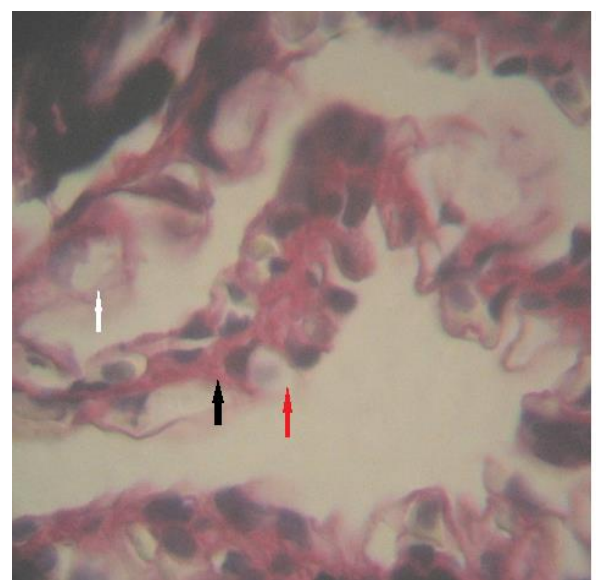

Figure 2. Lung cross section of Pelophylax ridibundus treated with Reldan 40EC and kept at a temperature of 4-6 ${ }^{\circ} \mathrm{C}$ Disorganized blood capillaries - white arrow, inactive pneumocytes - black arrow, hyalinized erythrocytes - red arrow. 400X. HE and Sirius red.

In the case of animals treated with the same toxic concentration but kept at a higher temperature $\left(22-24^{\circ} \mathrm{C}\right)$, the histological changes that occur in the lung are more pronounced. First-order longitudinal septa thicken even more, becoming almost rigid compared to those described in the control specimens. There is a presence of a larger number of connective cells, respectively fibroblasts, in the connective walls, their presence being associated with the accentuation of intraparietal fibrosis. First-order septa are bordered by a pseudostratified epithelium that disorganizes in some areas (figure 3). Also, the presence of many smooth muscle fibres along with elastic fibres is associated with a higher flow of air in the air sacs or airways. The presence of monocytic infiltrates in the blood capillaries is a response of the body to the toxic action of the insecticide Reldan 40EC. 


\section{Current Trends in Natural Sciences}

Vol. 10, Issue 20, pp. 122-129, 2021

https://doi.org/10.47068/ctns.2021.v10i20.017

Current Trends in Natural Sciences (on-line)

ISSN: 2284-953X

ISSN-L: 2284-9521
Current Trends in Natural Sciences (CD-Rom) ISSN: 2284-9521 ISSN-L: 2284-9521
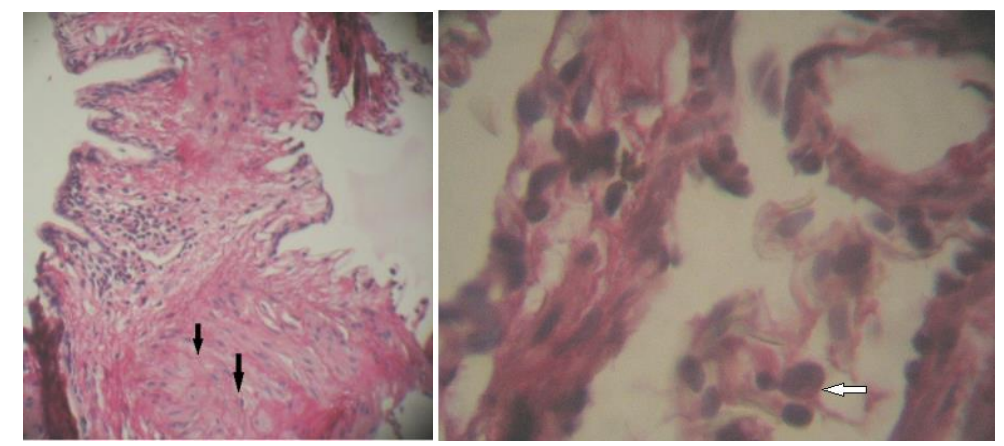

Figure 3. Lung of Pelophylax ridibundus treated with Reldan 40EC and kept at a temperature of $22-24^{\circ} \mathrm{C}$

Thickening of the conjunctival septa with the presence of large muscle fibres in large quantities (arrows) - left. Presence of monocytic infiltrates in the blood capillary - right. $100 X$ and $400 X, H E$ and Sirius red

Second-order septa also show a thickening, compared to the controls, and the smooth muscle fibers have longer elongated nuclei (figure 4a).
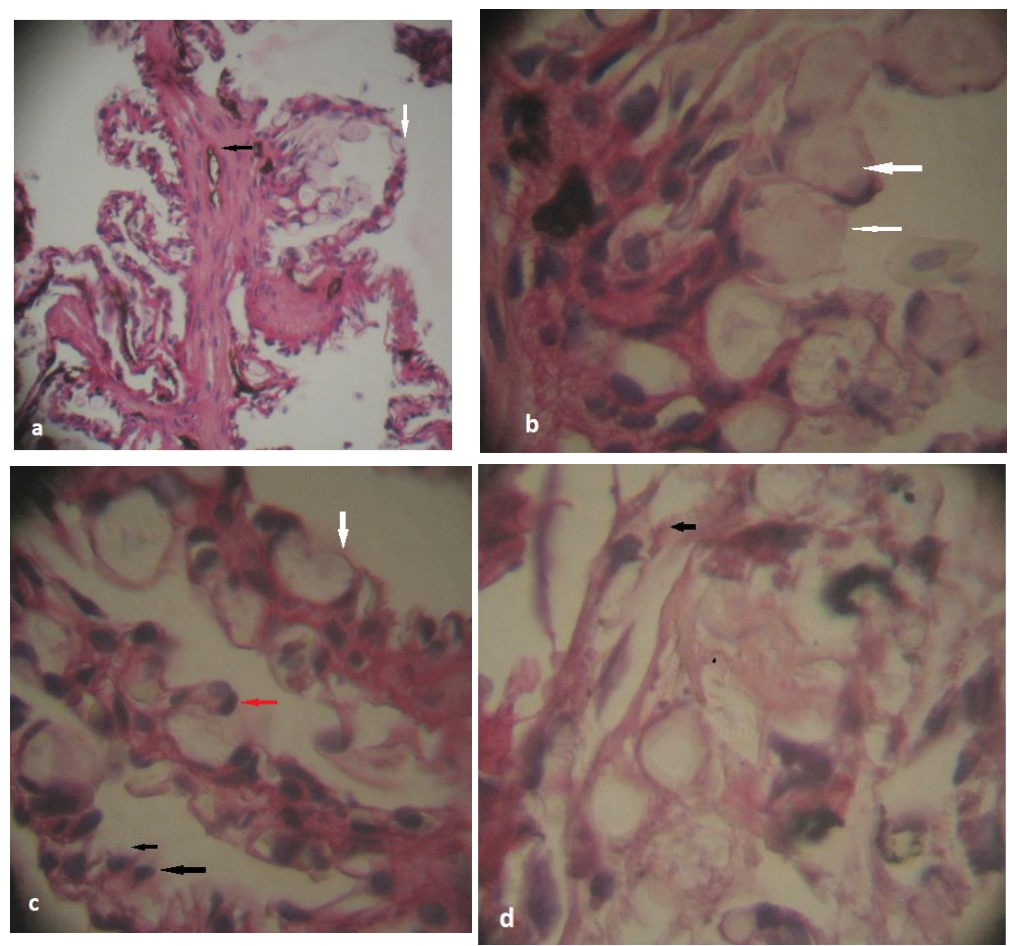

Figure 4. Lung de Pelophylax ridibundus treated with Reldan kept at a temperature of $22-24^{\circ} \mathrm{C}$

a - second-order conjunctivae thickened with smooth muscle fibres with elongated nuclei (black arrow); third-order conjunctivae bordered by a respiratory-type epithelium with numerous goblet cells (white arrow). 100X; $b$ -

hypertrophied goblet cells. 400X; $c$ - pneumocytes surrounded by lysed erythrocytes (red arrow), disorganized blood capillaries (white arrow), desquamation of the respiratory epithelium (black arrow). $400 \mathrm{X} ; \mathrm{d}$ - areas of histolysis with the presence of macrophage stellate cells. $400 \mathrm{X}, \mathrm{HE}$ and Sirius red

At the level of the third order septa, there are changes in the structure of the respiratory epithelium (figure $4 \mathrm{~b}$ ). Thus, the presence of a higher number of hypertrophied goblet cells accompanying pneumocytes is found, probably due to the need for a large amount of mucus with a protective 
function. Blood capillaries become disorganized; the pneumocytes are blocked by becoming inactive and are surrounded by lysed erythrocytes (figure 4c). There are areas where the respiratory epithelium flakes off. In the lung parenchyma there are some areas of histolysis in which the presence of macrophage stellate cells is noticed (figure 4d).

Similar changes have been reported in Pelophylax ridibundus specimens exposed to Roundup® herbicide: hyperplasia of the respiratory epithelium, an increase in the number of goblet cells, increasing the nucleus diameter of pneumocytes, interstitial oedema, presence of melanin deposit (Păunescu et al., 2012). Highly degenerative changes in lung tissue such as interstitial oedema, presence of melanin deposit, an increase in the number of hyperplasiated and active goblet cells, were evident in animals that was treated with toxic and kept at $22-24^{\circ} \mathrm{C}$. Șișman et al., 2021 reported histopathological alterations in lung tissue in marsh frog (Pelophylax ridibundus) in agricultural areas: epithelial hyperplasia, thickness of alveolar septa, dilatations and congestions of blood capillaries, and melanomacrophage accumulation. Păunescu et al reported a series of histopathological changes induced by exposure of Pelophylax ridibundus specimens to Reldan insecticide in various reactive organs: liver (Păunescu et al, 2010), skin (Păunescu et al, 2010) and gall-bladder (Păunescu et al, 2010), as well as a series of changes in some physiological parameters (Păunescu et al, 2009): increases in erythrocyte count and glycaemia value and a decrease in leukocyte count.

To study the toxic effect of Reldan 40EC on pneumocytes, we calculated the ratio of nucleus diameter to pneumocyte diameter and applied the statistical test $t$ (Student) for $\mathrm{p}<0.05$.

Table 1. Ratio of nucleus diameter to pneumocyte diameter

\begin{tabular}{ccc}
\hline Lot & Number of measurements & Average and standard deviation \\
\hline C $4-6^{\circ} \mathrm{C}$ & 200 & $0.58 \pm 0.029$ \\
Lot I & 200 & $0.62 \pm 0.021$ \\
C 22-24 ${ }^{\circ} \mathrm{C}$ & 200 & $0.75 \pm 0.022$ \\
Lot II & 200 & $0.83 \pm 0.018$
\end{tabular}

\section{CONCLUSIONS}

These observations lead us to conclude that Reldan 40 EC in a dose of $0.1 \mathrm{ml}$ chlorpyrifos/g of body weight determinates morphologic modifications in the lung tissues of Pelophylax ridibundus in both thermic variants (at $4-6^{\circ}$ and at $22-24^{\circ} \mathrm{C}$ ).

Lung tissue of the frogs showed marked pathological changes such as: increase in the number of goblet cells (which are also hyperplasiated), disorganization of blood capillaries, signs of fibrosis. Also, pneumocytes react by increasing the nucleus diameter in relation to the cell diameter. Highly degenerative changes in lung tissue were evident in animals that were treated with toxic and kept at $22-24^{\circ} \mathrm{C}$. This study demonstrates a direct correlation between insecticide exposure and histopathological disorders observed in lung tissues.

Also, a temperature of $4-6{ }^{\circ} \mathrm{C}$ determines the presence of smaller nuclei in pneumocytes, while at a temperature of $22-24{ }^{\circ} \mathrm{C}$ there is an increase in the volume of the nuclei, which is highlighted in the expression of the ratio between the diameter of the nucleus and the diameter of the pneumocyte. 


\section{Current Trends in Natural Sciences}

Vol. 10, Issue 20, pp. 122-129, 2021

https://doi.org/10.47068/ctns.2021.v10i20.017

Current Trends in Natural Sciences (on-line)

ISSN: 2284-953X

Current Trends in Natural Sciences (CD-Rom)

ISSN: 2284-9521

ISSN-L: 2284-9521

ISSN-L: 2284-9521

\section{REFERENCES}

Beasley, V. R. (2020). Direct and Indirect Effects of Environmental Contaminants on Amphibians. Reference Module in Earth Systems and Environmental Sciences. Retrieved November 2021, from https://www.sciencedirect.com/science/article/pii/B9780124095489112746

Bernabo, I., Sperone, E., Tripepi, S., Brunelli, E. (2011). Toxicity of Chlorpyrifos to Larval Rana dalmatina: Acute and Chronic Effects on Survival, Development, Growth and Gill Apparatus. Arch Environ Contam Toxicol, 61:704718, Retrieved November 2021 from https://link.springer.com/article/10.1007/s00244-011-9655-1

Blaustein, A.R., Walls, S.C., Bancroft, B.A., Lawler, J.J., Searle, C.L., Gervasi, S.S. (2010). Direct and Indirect Effects of Climate Change on Amphibian Populations. Diversity, 2, 281-313. Retrieved November 2021 from https://doi.org/10.3390/d2020281

Bridges, C.M., Boone, M.D. (2003). The interactive effects of UV-B and insecticide exposure on tadpole survival, growth and development. Biol Conserv 113:49-54.

Casida, J.E. and Quistad, G.B. (2004). Organophosphate toxicology: Safety aspects of nonaacetylcholinesteraze secondary targets. Chem. Res. Toxicol., 17, 983-998.

El-Merhibi A., Kumar A., Smeaton T. (2004). Role of piperonyl butoxide in the toxicity of chlorpyrifos to Ceriodaphnia dubia and Xenopus laevis. Ecotoxicology and environmental safety. 57(2): 202-212.

Giesy, J.P., Solomon, K.R., Coates, J.R., Dixon, K.R., Giddings, J.M., Kenaga, E.E. (1999). Chlorpyrifos: ecological risk assessment in North American aquatic environments. Rev Environ Contam Toxicol 160:96-102.

Gonzalez-Mille, D.J., Espinosa-Reyes, G., Rivero-Pérez, N.E., Trejo-Acevedo, A., Nava-Montes, A.D. and IlizaliturriHernández, C.A. (2013). Persistent organochlorine pollutants (POPs) and DNA damage in giant toads (Rhinella marina) from an industrial area at Coatzacoalcos, Mexico. Water Air Soil Pollut., 224: 1781-1795. Retrieved October 2021 from https://link.springer.com/article/10.1007/s11270-013-1781-0

Greulich, K., Pflugmacher, S. (2004). Uptake and effects on detoxication enzymes of cypermethrin in embryos and tadpoles of amphibians. Journal Archives of Environmental Contamination and Toxicology 47:489-495.

Hayes, T.B., Case, P., Chui, S., Chung, D., Haeffele, C., Haston, K. et al. (2006). Pesticide mixtures, endocrine disruption, and amphibian declines: are we underestimating the impact? Environ Health Perspect 2006; 114:4050 .

Houlahan, J.E., Findlay, C.S., Schmidt, B.R., Meyer, A.H., Kuzmin, S.L. (2000). Quantitative evidence for global amphibian population declines. Nature 2000;404(6779):752-5.

Juncueira, L.C.U., Bignolas, G., Brentani, R.R. (1979). Picrosirius staining plus polarization microscopy, a specific method for collagen detection in tissue section. Histochemical Journal 11: 447-455.

Kiely, T., Donaldson, D., Grube, A. (2004). Pesticides industry sales and usage. 2000 and 2001 market estimates. Washington, DC: U.S. Environmental Protection Agency, Report No. EPA-733-R-99-001. Retrieved November 2021, from https://nepis.epa.gov/Exe/ZyPDF.cgi/3000659P.PDF?Dockey=3000659P.PDF

Koshlukova, S. E., and Reed, N. R. (2014). Chlorpyrifos. Encyclopaedia of Toxicology, 930-934. Retrieved November 2021, from https://www.researchgate.net/publication/301950918_Chlorpyrifos

Öztay, F. (2000). Morphology of Lung of Rana ridibunda with Observations on Changes Occurring under Different Conditions. Turk. J. Zool. 24: 263-270.

Păunescu, A., Ponepal, M.C., Dima, R., Grigorean, V.T., Valentin, T. and Popescu, M. (2012). Histopathological changes in marsh frog (Pelophylax ridibundus) lung tissue induced by the action of Roundup® herbicide. Oltenia Stud. Comun. Ştiinţele Nat., 28: 114-118.

Păunescu, A., Ponepal, M.C., Drăghici, O., Marinescu, Al.G. (2009). The influence of Reldan 40EC insecticide upon physiological indices in Rana ridibunda. Scientific Papers USAMV Bucharest series B, vol LIII: 743-746.

Păunescu, A., Ponepal, M.C., Drăghici, O., Marinescu, Al.G. (2010). The influence of Reldan 40EC and Actara 25WG insecticide upon gall-bladder structure in Rana (Pelophylax) ridibunda. Scientific Papers USAMV Bucharest, Series B, vo.LIV:808-811.

Păunescu, A., Ponepal, M.C., Drăghici, O., Marinescu, Al.G. (2010). Liver histopathologic alterations in the frog Rana (Pelophylax) ridibunda induce by the action of Reldan 40EC insecticide. Analele Universitatii din Oradea, Fascicula Biologie, tom VXII (1):166-169.

Păunescu, A., Ponepal, M.C., Drăghici, O., Marinescu, Al.G. (2010). Histological changes induced by the action of the insecticide Reldan 40EC in Rana ridibunda. Scientific papers Journal, Horticulture series, "Ion Ionescu de la Brad", University of Agricultural Sciences and Veterinary Medicine of Iasi, vol.53:637-642. 


\section{Current Trends in Natural Sciences}

Vol. 10, Issue 20, pp. 122-129, 2021

https://doi.org/10.47068/ctns.2021.v10i20.017

Current Trends in Natural Sciences (on-line)

ISSN: 2284-953X

Current Trends in Natural Sciences (CD-Rom)

ISSN: 2284-9521

ISSN-L: 2284-9521

ISSN-L: 2284-9521

Păunescu, A., Ponepal, M.C., Marinescu, Al.G. (2011). Lung toxicity induced by the action of Champion 50WP fungicide in marsh frog (Pelophylax ridibundus). Studia Universitatis "Vasile Goldis", Seria Stiintele Vietii, Vol. 21(2):355-360.

Picoş, C.A., Năstăsescu, Gh. (1988). Lucrări practice de fiziologie animală. Editura Universităţii din Bucureşti, 228p.

Richards, S.M., Kendall, R.J. (2002). Biochemical effects of chlorpyrifos on two developmental stages of Xenopus laevis. Environ Toxicol Chem 21:1826-1835.

Richards, S.M., Kendall, R.J. (2003). Physical effects of chlorpyrifos on two stages developmental stages of Xenopus laevis. J Toxicol Environ Health A 66:75-91.

Schreck, C.B., Brouha, P. (1975). Dissolved oxygen depletion in static bioassay systems. Bull Environ Contam Toxicol $1975 ; 14(2): 149-52$.

Şişman, T., Keskin, M.C., Dane, H., Adil, Ș., Geyikoğlu, F., Çolak, S. and Canpolat, E. (2020). Marsh Frog (Pelophylax ridibundus) as a Bioindicator to Assess Pollution in an Agricultural Area. Pakistan Journal of Zoology 53, pp.113. Retrieved November 2021 from https://www.researchgate.net/publication/342793011_Marsh_Frog_ Pelophylax ridibundus as a Bioindicator to Assess Pollution in an Agricultural Area

Soloneski, S., de Arcaute, C.R. and Larramendy, M.L. (2016). Genotoxic effect of a binary mixture of dicamba and glyphosate-based commercial herbicide formulations on Rhinella arenarum (Hensel, 1867) (Anura, Bufonidae) late-stage larvae. Environ. Sci. Pollut. Res., 23: 17811-17821. Retrieved November 2021 from https://link.springer.com/article/10.1007\%2Fs11356-016-6992-7

Sparling, D.W. (2003). A review of the role of contaminants in amphibian declines. In: Hoffman D J, Rattner B A, Burton G A Jr, Cairns J Jr, ed. Handbook Ecotoxicology, Lewis, Boca Raton, Florida, USA, 1099-128.

Sparling, D.W., Fellers, G. (2007). Comparative toxicity of chlorpyrifos, diazinon, malathion and their oxon derivatives to larval Rana boylii. Environ Pollut 147:535-539.

Srivastav, A.K., Srivastava, S., Srivastav, S.K., Suzuki, N. (2017). Acute Toxicity of an Organophosphate Insecticide Chlorpyrifos to an Anuran, Rana cyanophlyctis. Iranian Journal of Toxicology, Volume 11, No 2, 45-49.

Török, Z., Covaciu-Marcv, S., Sas-Kovacs, I., Török, L. (2019). Documentație tehnică pentru secțiunea referitoare la Pelophylax ridibundus din publicația "Ghid de monitorizare a speciilor de reptile și amfibieni de Interes Comunitar din România”. Versiunea 1 (mai 2019). Project: Reporting Conservation Status of Romanian Amphibians and Reptiles of Community Interest under Art. 17 of European Council Directive 92/43/CEE. Retrieved October 2021 from https://www.researchgate.net/publication/338701778_Documentatie tehnica_pentru_sectiunea_referitoare la_P elophylax_ridibundus_din_publicatia_Ghid_de_monitorizare_a_speciilor_de_reptile_si_amfibieni_de_Interes_C omunitar_din_Romania_Versiunea_1_mai_2019

Trudeau, V.L., Thomson, P., Zhang, W.S., Reynaud, S., Navarro-Martin, L., Langlois, V.S. (2020). Agrochemicals disrupt multiple endocrine axes in amphibians. Molecular and Cellular Endocrinology, Volume 513, $110-861$. Retrieved November 2021 from https://doi.org/10.1016/j.mce.2020.110861

Uzun, F.G., Demir, F., Kalender, S., Bas, H., Kalender, Y. (2010). Protective effect of catechin and quercetin on chlorpyrifos-induced lung toxicity in male rats. Food and Chemical Toxicology 48: 1714-1720.

Whittaker, K., Koo, M.S., Wake, D.B. and Vredenburg, V.T. (2013). Global declines of amphibians. In: Encyclopaedia of biodiversity (ed. S.A. Levin), second ed. Academic, Waltham, USA, pp. 691-699. Retrieved November 2021 from https://doi.org/10.1016/B978-0-12-384719- 5.00266-5

Widder, P.D., Bidwell, J.R. (2008). Tadpole size, cholinesterase activity, and swim speed in four frog species after exposure to sub-lethal concentrations of chlorpyrifos. Aquat Toxicol 88: 9-18.

Yin, X., Zhu, G., Li, X.B., Liu, S. (2009). Genotoxicity evaluation of chlorpyrifos to amphibian Chinese toad (Amphibian: Anura) by comet assay and micronucleus test. Mutat Res Genet Toxicol Environ Mutagen 2009;680(1):2-6.

Zhelev, Z., Tsonev, S., Georgieva, K. and Arnaudova, D. (2018). Health status of Pelophylax ridibundus (Amphibia: Ranidae) in a rice paddy ecosystem in Southern Bulgaria and its importance in assessing environmental state: haematological parameters. Environ. Sci. Pollut. Res., 25: 7884-7895. Retrieved November 2021, from https://doi.org/10.1007/s11356-017-1109-5

* Corresponding author, E-mail address: magda.diaconu@yahoo.com 